\title{
Exploration on SPOC-based Blended Teaching Strategies in Business English Reading Course
}

\author{
Jinchun Zhang ${ }^{1}$, Dongshui Zhang ${ }^{1}$ \\ ${ }^{1}$ Department of Foreign Language and Literature, Nanchang University Gongqing College, Gongqingcheng, Jiangxi, 332020, China
}

\begin{abstract}
As the new direction of education reform in the internet era, the SPOC-based blended teaching mode has become increasingly popular in universities, because it can enrich teaching content, diversify learning path, enhance interaction between teachers and learners, and most importantly improve students' learning enthusiasm and effectiveness. However, due to the lack of substantial knowledge and strategies on SPOC-based teaching concept as well as computer technology, many English teachers cannot conduct SPOC-based blended teaching mode well in their classes even though they have the intention to do it well. Therefore, taking business English reading course as a case study, this paper explores some effective strategies on how to apply SPOC-based blended teaching in English courses, so as to provide useful enlightenment for foreign language teachers in universities and colleges to better conduct blended teaching in their classes in the future.
\end{abstract}

\section{Introduction}

Since the 1980s, information technology began to penetrate into every part of education field as a result of the development of Internet technology. In late 1980s, the research on computer-aided language teaching began to become a hot issue. The study of COMPUTER-aided language teaching has also brought about great changes in classroom teaching and learning. For example, in the classroom teaching assisted by multimedia technology, learning resources have developed from a single textbook in the traditional classroom to multimedia files with sound, text, pictures, video images and so on. What's more, with the fast development and promotion of MOOC technology in China in the past decade, the construction capacity of MOOC high-quality courses in colleges and universities has been greatly enhanced, and it has also achieved great success. According to the statistics of China's higher Education Department of the Ministry of Education, more than 10 MOOC platforms have been built in China, such as MOOC platforms for Chinese college students, MOOC platforms for Foreign languages in Chinese Colleges and Universities, and Chaoxing Xuexitong. There are about 12,500 MOOC courses online. Under this trend, MOOCs in foreign languages are developing continuously (Huang Kaisheng, Zhou Xinping, 2017)[1].

As a result, offline classes are being replaced by online classes based on MOOCs. However, many disadvantages of MOOC online learning gradually emerge, such as low course pass rate, single platform mode, lack of big breakthrough compared with traditional classroom teaching, lack of interaction between teachers and students, which is not conducive to further development of deep learning, and the application effect in the actual teaching is not ideal. In 2019, the Ministry of Education launched the "Double Tenthousand Curriculum Plan", which clearly proposed to strengthen the construction and application of first-class courses (" Golden courses ") and online courses, and vigorously promote blended teaching. Therefore, in postMOOC era, blended teaching mode will become the new direction of future teaching. Based on the Blended teaching of Business English reading Course based on SPOC, this paper explores effective teaching strategies that college English teachers can adopt when conducting Blended teaching. The research results are beneficiary to the promotion of the blended teaching ability for foreign language teachers.

\section{SPOC blended teaching}

Foreign research on Blended teaching discussion can be traced back to the late $1990 \mathrm{~s}$, proposed by foreign training institutions. It combines the traditional learning method with the online digitalization and networking, which not only guarantees the leading role of teachers and the main role of students, but also improves the learning efficiency and benefits of students. It is a new ideal and efficient teaching method. Its essence is the systematic integration of teachers, students and learning

virginia1985@126.com 
resources (He Kekang, 2004[2]; Garrison \& Kanuka, 2004[3]).

In 2013, Professor Fox of University of California proposed the idea of SPOC (Small Private Online Course), which is to realize the organic integration of Online MOOC and offline classroom teaching. SPOC advocates mixed online and offline courses, combining the interaction between teachers and students in physical classrooms and the ubiquitous learning mode of "Internet $+"$ virtual space. It can effectively make up for the shortcomings of the superficial network teaching, break the limitation of learning time and space, expand the extension of classroom learning, and provide an operational mode for the deep integration of modern information technology and classroom teaching (Zhang Xiaojuan, Li Lijie, 2018) [4]. SPOC Blended teaching is getting more and more attention in foreign language teaching. Chen Jianlin (2015) proposed that the combination of online and offline teaching is an effective way to achieve efficient foreign language learning. The combination of online and offline activities can also effectively overcome the poor learning performance of students who often suffer from a strong sense of loneliness and lack of external assistance and motivation [5]. In January 2017, the State Council released the "13th Five-Year Plan for The Development of National Education" and the " Double Ten-thousand Curriculum" launched by the Ministry of Education in 2019, both of which are fully promoting the in-depth integration of information technology and education and teaching, promoting the development of blended teaching mode, and striving to form a new learning mode organically combining online and offline teaching-SPOC blended teaching.

At present, there have been a lot of practice and research on SPOC mode, but most of them are limited to the characteristics of SPOC theory itself, and there is a lack of research on SPOC-based Blended teaching strategies for a specific English course.

\section{The necessity of adopting blended teaching in business English reading course}

Business English Reading is a core course for business English majors and one of the key practical training courses. This course is not suitable for the full online teaching mode due to its characteristics such as wide range of knowledge, great learning difficulty, strong business practicability and quick content update. That's why no school has launched an online business English reading course on any MOOC platform so far. Taking the current university where the author works as an example, the teaching of business English reading still adopts the traditional offline classroom teaching mode. According to the author's investigation, in the traditional offline classroom teaching practice, there are the following problems.

\subsection{Difficult to teach this course by teachers}

Business English itself has the characteristic of "interdisciplinary", aiming at cultivating compound talents who can both understand business knowledge and skillfully use English skills, so it is very difficult to prepare lessons. At the same time, college Business English reading course has a small amount of class time, which is basically once a week ( 2 periods).In class, many teachers are even difficult to complete the detailed explanation of the words, phrases, sentences and discourse structure of all articles in the whole book. Therefore, this course has a high requirement for teachers' teaching design and teaching ability.

\subsection{Hard to learning this course independently by students.}

The college where the author works is an ordinary undergraduate college, so the students' business background knowledge and English language foundation are relatively weak. When students are reading business English articles, they find it difficult to understand because of the considerable professional terms and long difficult sentences. So, students find it difficult to study independently without the help of a teacher. In addition, In the extracurricular reading of many college students, they do not develop the habit of reading to expand their horizons. They read more Original English books and less business newspapers, which leads to less training in corresponding reading methods and slow improvement in business English reading ability.

\subsection{Low learning interest and poor learning result}

The business world in reality is ever-changing and business knowledge is updated quickly. However, it takes a certain amount of time for business English reading textbooks to reach students from publication, which makes the articles in them easily outdated and the information provided cannot keep up with the hot information of the society. As a result, students tend not to be interested in reading the textbook articles. In addition, if the teacher adopts the traditional teaching mode, the teaching method is single, and the students' learning enthusiasm is not high.

Based on the above reasons, it is necessary to reform the existing offline teaching mode of business English reading course. It is of certain practical significance and has reference value to explore the implementation strategies of blended teaching in business English reading course based on SPOC.

\section{Strategies suggested for SPOC- based Blended teaching in Business English Reading Course}

The blended teaching mode is usually composed of three modules: "before class + during class + after class". In the process of blended teaching of specific business 
English reading, it is necessary to combine the characteristics of business English reading course and SPOC mode to decide when to use offline teaching mode or online mode to learn what kind of content. Teachers should effectively combine the advantages of online platform and offline face-to-face teaching, rationally allocate learning resources, learning time and place, and realize the optimal combination mode of online and offline teaching. In the specific operation process, the following three different combination strategies can be adopted when deciding whether to learn the content offline or online.

\subsection{Strategy 1: Requiring preview before class + lecturing in class + testing after class}

In this blended teaching strategy, pre-class preparation is completed online, in-class teaching is conducted offline, and after-class testing is done online.

Table 1. preview, lecture and test.

\begin{tabular}{|c|c|c|}
\hline Module & Teaching content & Teaching means and technology media \\
\hline Preview & $\begin{array}{l}\text { Text background } \\
\text { Language points }\end{array}$ & $\begin{array}{l}\text { Online learning, preview tasks given by teachers } \\
\text { through WeChat or QQ platform (videos or } \\
\text { documents) }\end{array}$ \\
\hline Lecture & $\begin{array}{l}\text { Extra knowledge } \\
\text { Difficult sentences } \\
\text { text structure analysis }\end{array}$ & $\begin{array}{l}\text { Offline learning, participate in class activities } \\
\text { PPT, learning Apps, websites }\end{array}$ \\
\hline Test & $\begin{array}{l}\text { Knowledge review } \\
\text { and consolidation }\end{array}$ & $\begin{array}{l}\text { Online exercise, group discussion, MOOC } \\
\text { platforms, data collection }\end{array}$ \\
\hline
\end{tabular}

Before the beginning of each unit, teachers can release preview tasks (videos or documents) to students via social networking platforms such as QQ group and WeChat group, like thinking on business topics, doing vocabulary preview or reading text guide materials, etc. Let students get the background of the text theme in advance in order to help students to improve efficiency during class. In classroom teaching, teachers focus on the expansion of language knowledge, structure analysis, and explanation of difficult sentences. In addition, students can also be organized to participate in some language output activities, such as vocabulary dictation, paragraph reading, discussion and so on. Through these activities, teachers, as observers, can timely find students' weak points in phonetics, vocabulary, grammar and other language aspects, and then give targeted guidance through comments to help them improve. After class, teachers can arrange online exercises through relevant platforms for review and consolidation. Online exercises can be set for automatic grading, which greatly improves the efficiency of teachers' homework grading. At the same time, through big data analysis, the teacher can know how the students have mastered the knowledge points and find out the weak points, so that they can timely supplement the explanation to those weak points for students in next class. This is more targeted than traditional classroom assignments. What's more, learning groups can also be set up so that students can communicate and discuss with each other at any time through social platforms when they encounter difficulties in homework.

In a word, using online platform to assign homework not only increases the interaction opportunities between teachers and students, but also provides teachers with reliable data basis for students' performance evaluation.

\subsection{Strategy 2: Demanding self-study before class + Conducting seminars in class + Answering questions after class}

In this blended teaching strategy, students' self-study before class is completed online, discussion in class is conducted offline, and Answering questions after class is run online.

Table 2. self-study, seminar and Q\&A.

\begin{tabular}{lll}
\hline Module & \multicolumn{1}{c}{ Teaching content } & Teaching means and technology media \\
\cline { 2 - 3 } Self-study & $\begin{array}{l}\text { Business Knowledge } \\
\text { Language points }\end{array}$ & $\begin{array}{l}\text { Online learning, learn unit-teaching videos on } \\
\text { MOOC platforms or Xuexitong }\end{array}$ \\
Seminar & $\begin{array}{l}\text { Similar theme articles } \\
\text { Difficult sentences } \\
\text { text structure analysis } \\
\text { Critical thinking } \\
\text { and review }\end{array}$ & $\begin{array}{l}\text { Offline learning, participate in class discussion, } \\
\text { electronic dictionaries, searching websites }\end{array}$ \\
& & $\begin{array}{l}\text { Online communication, group discussion, } \\
\text { answering questions, problem collection }\end{array}$ \\
\hline
\end{tabular}


Before class, teachers record their teaching courseware into micro-course videos and upload them through the school's online system, such as Xuexitong, then, ask students to complete the learning tasks in the online learning platform. All knowledge points in the textbook will be mastered by students themselves in the preview process. During class discussion, teachers prepare business English articles on similar topics and encourage students to read quickly, which not only broadens their business vision but also exercises their reading skills. What's more, teachers allow students to use smart phones during class. Because with the help of various learning assistance programs and search engine functions, students can search and consult knowledge difficulties encountered and solve problems themselves as well as through mutual discussion. After class, teachers will answer questions and regularly communicate with students through the online learning platform, classify and sort out the problems encountered by students in the learning process, and list typical problems as topics for discussion in the next class. In this strategy, online platforms are used before and after class, which can track and analyse students' learning participation and learning preference, facilitate teachers to understand students' learning trends, and help improve the teaching effect.

\subsection{Strategy 3: Setting questions before class + Asking presentation in class + Conducting discussions after class}

In this Blended teaching strategy, pre-class questions are completed offline, in-class presentations are given offline, and after-class discussions are conducted online.

Table 3. question, presentation and discussion.

\begin{tabular}{|c|c|c|}
\hline Module & Teaching content & Teaching means and technology media \\
\hline Question & $\begin{array}{l}\text { Text theme } \\
\text { Language points }\end{array}$ & $\begin{array}{l}\text { Offline learning, answering questions given by } \\
\text { teachers through WeChat or QQ platform }\end{array}$ \\
\hline Presentation & $\begin{array}{l}\text { background knowledge } \\
\text { Difficult sentences } \\
\text { text structure analysis }\end{array}$ & $\begin{array}{l}\text { Offline learning, give presentation in class } \\
\text { PPT including words, pictures, videos and so on }\end{array}$ \\
\hline Discussion & $\begin{array}{l}\text { Self-correction /improvemen } \\
\text { to } \\
\text { previous presentation }\end{array}$ & $\begin{array}{l}\text { t Online learning, group discussion, } \mathrm{MOOC} \\
\text { platforms, data collection }\end{array}$ \\
\hline
\end{tabular}

Before the class, the teacher sets a number of questions around the unit theme, with the same number as the students' discussion groups. Then the group members discuss and research within the group, and form the report materials. In class, words, pictures, videos and PPTs will be presented by each group's representatives. Meanwhile, other team members can ask questions to the presentation team, which will be answered by the reporting team members. After class, the teacher uploads the analysis text of business English articles related to the text, or shares the micro-course resources with the students, so that the students can continue to discuss and summarize the shortcomings in their previous discussions, thereby improving their independent learning ability.

This strategy emphasizes that the basis of blended teaching is team or group learning, and team discussion breaks the pattern of individual teachers facing the whole class. Teachers mainly play an intermediary, coordinating and leading role, while students are the main body of learning. What's more, In after-class seminars, teachers should add their own exercises and cases to avoid repetition of online and offline content

Finally, in the process of constructing a blended teaching mode of business English reading course based on SPOC, teachers should integrate the evaluation system of process assessment and finalization assessment throughout the inside and outside of the classroom (Wang Shurui., 2019) [6]. The evaluation system on the online teaching platform in the information age can help teachers collect, analyse and manage data, so as to carry out learner analysis and evaluate students' learning behaviour and effect effectively and rationally.

\section{Conclusion}

The development of modern educational technology has optimized the way of acquiring knowledge, which not only provides more teaching materials for language teaching, but also urges foreign language teachers to reform their classroom teaching mode. However, the emergence of online teaching mode does not mean that it can completely replace all the advantages of traditional physical classroom. SPOC based blended teaching model makes full use of the advantages of online teaching with abundant resources and unlimited time and space, combines with the advantages of offline teaching in faceto-face communication and systematic guiding, and avoids the disadvantages of both, so as to better improve the quality of classroom teaching. So, teachers should strive to improve their ability of using information technology and update teaching concepts. By exploring the diversified strategies of blended teaching, we can create an effective learning environment and rationally design teaching activities to improve the classroom teaching effect. Meanwhile, schools should also invest more in building a learning resource database, improve the blended teaching performance reward mechanism, 
support teaching research and reform projects related to blended teaching, and build SPOC-based blended teaching college English curriculum group and academic community.

\section{Acknowledgments}

I'd like to present my sincere thanks to professor Peng Yinmei, Dean of the department of foreign language and Literature in Gongqing College of Nanchang University, for giving me so many help in doing the survey about the current situation of Business English reading class teaching, and some suggestions for blended teaching in this course.

\section{References}

1. Huang Kaisheng, Zhou Xinping. Investigation on the construction and application of MOOCs in foreign language in China $[\mathrm{J}]$. Modern Educational Technology, 2017(12).

2. He Kekang On the new development of educational technology theory from the perspective of blending learning [J]. Audio-visual Education Research 2004 (3).

3. Garrison, D.R.\&H. Kanuka. Blended Learning: Uncovering its transformative potential in higher education $[\mathrm{J}]$ Internet and Higher Education,2004(7).

4. Zhang Xiaojuan, Lu Lijie. Construction of classroom learning community pointing to deep learning [J]. Basic Education, 2015,15, (3): 35-41.

5. Chen Jianlin. Research on MOOC and foreign language teaching in the era of big data -challenges and opportunities $[\mathrm{J}]$. Foreign Language Audio-Visual Teaching,2015, (1): 3-8 +16 .

6. Wang Shurui, Zheng Erdong, Wang Yongqin. Online and offline integrated college English teaching practice $[\mathrm{J}]$. Heilongjiang Education (Theory and Practice),2019, (9): 79-81. 